J. Clin. Chem. Clin. Biochem.

Vol. 27, 1989, pp. 277-285

(C) 1989 Walter de Gruyter \& Co.

Berlin - New York

\title{
Characterisation of a Carboxypeptidase in Human Serum Distinct from Carboxypeptidase $\mathrm{N}$
}

\author{
By D. Hendriks, S. Scharpé, M. van Sande and M. P. Lommaert \\ Department of Medical Biochemistry, Faculty of Medicine, University of Antwerp, Wilrijk, Belgium
}

(Received August 15/November 24, 1988)

Summary: Arginine carboxypeptidase activity in human serum, measured with the hippuryl- $L$-arginine substrate, is about three times higher than in human plasma. This difference is much smaller when hippuryl- $L$ lysine is used as the substrate. When fresh serum is incubated at $30^{\circ} \mathrm{C}$, the arginine and lysine carboxypeptidase activity decreases until a stable activity, close to the plasma activity, is reached. This stable carboxypeptidase activity is attributed to carboxypeptidase $\mathrm{N}$. The unstable carboxypeptidase differs from carboxypeptidase $\mathrm{N}$ in $\mathrm{pH}$-optimum, esterase activity, substrate specifity, $\mathrm{Co}^{2+}$-activation and dithiotreitol activation. Blood cells are not responsible for the release of this enzyme during coagulation. No activator of carboxypeptidase $\mathrm{N}$ was detectable in human serum. Ion-exchange chromatography on DEAE-cellulose confirms the presence of two different molecular forms of arginine carboxypeptidase activity.

\section{Introduction}

Carboxypeptidase N (arginine carboxypeptidase, kininase I) ${ }^{1}$ ) cleaves carboxy-terminal arginine and lysine from various peptides in human plasma. Some of the most interesting substrates for this enzyme are the kinins, bradykinin and kallidin (1), the anaphylatoxins $C_{3 a}, C_{4 a}$ and $C_{5 a}(2,3)$, fibrinopeptides $6 A$ and $6 \mathrm{D}$ (4), the creatine kinase MM-isoenzyme $(5,6)$, hexapeptide enkephalins (7) and the atrial natriuretic peptide atriopeptin II (8).

A number of papers deal with the determination of the activity of carboxypeptidase $\mathrm{N}$ in human serum $(9-23)$ or in plasma $(24)$ in various pathological conditions. Here we describe and characterize the important difference in carboxypeptidase activities between fresh serum, on the one hand, and older serum or heparinized plasma on the other, depending on the substrate used. We present evidence of a new carboxypeptidase activity in fresh human serum which has some characteristics in common with carboxypeptidase $\mathbf{N}$.

\section{Materials and Methods}

\section{Chemicals}

Hippuryl- $L$-arginine (Hip-Arg), hippuryl- $L$-lysine (Hip-Lys), 3(2-furylacryloyl)-alanyl-L-lysine (furylacryloyl-Ala-Lys), $p$-hydroxy-hippuryl-L-arginine ( $\mathrm{OH}$-Hip-Arg), and $p$-hydroxy-hippuryl-L-lysine ( $p \mathrm{OH}-\mathrm{Hip}-\mathrm{Lys}$ ) were from Bachem Feinchemikalien (Bubendorf, Switzerland). D,L-2-Mercaptomethyl-3guanidinoethylthiopropanoic acid and 4-(2-hydroxyethyl)-1-piperazineethane-sulphonic acid (HEPES) were purchased from Calbiochem (La Jolla, CA, USA). Phenylmethylsulphonylfluoride, diisopropylfluorophosphate, heparin (Na-salt), and DEAEcellulose (microgranular form) were obtained from Sigma (St. Louis, MO, USA) and dithiotreitol from Janssen Chimica (Beerse, Belgium).

$\mathrm{CoCl}_{2} \cdot 6 \mathrm{H}_{2} \mathrm{O}$ was from Aldrich Chemical Company (Milwaukee, WI, USA). 3-(2-Furylacryloyl)-alanyl- $L$-arginine (furylacryloyl-Ala-Arg) was a kind gift of Dr. Thomas $H$. Plummer, Jr., New York State Department of Health (Albany, NY, USA) and hippuryl- $L$-argininic acid was kindly provided by Dr. Yehuda Levin of the Weizmann Institute of Science, Rehovot, Israel. $o$-Methylhippuric acid was synthesized from glycine and $o$-methylbenzoylchloride (UCB, Drogenbos, Belgium) by a procedure analogous to that used for the synthesis of hippuric acid (25).

All other reagents used were of high purity grade and were from Merck, (Darmstadt, FRG).

\footnotetext{
1) Enzyme

Carboxypeptidase N, EC 3.4.17.3
} 


\section{Instruments}

The pipetting of serum samples and reagents was performed with a Dilutrend dispenser (Boehringer, Mannheim, FRG). For colorimetric determinations a Hewlett-Packard 8540 ultraviolet/visible diode-array spectrophotometer was used with a quartz flow cell (10 mm optical pathway). The high performance liquid chromatography system consisted of a 303 solventdelivery system, an $802 \mathrm{C}$ manometric module, a model 231 401 autosampling injector (all from Gilson, Paris, France), an LKB 2140 diode-array UV detector (LKB, Bromma Sweden), and a $100 \times 8 \mathrm{~mm}$ (i.d.) $\mathrm{C}_{18}$ reversed-phase $\mu$-Bondapak column fitted in a radial compression module (Millipore, Brussels, Belgium).

Routine coagulation analyses were performed on a Coagulab 40A automatic coagulation analyser (Ortho Diagnostics, Rariton, NJ, U.S. A.).

\section{Blood Samples}

From five healthy individuals (laboratory staff, three males, two women) blood samples were taken (in no additive, silicone coated tubes, and in lithium heparin tubes (Vacutainer, Becton and Dickinson, Rutherford, NJ, U.S.A.). All samples were placed in ice for $1 \mathrm{~h}$ to allow clotting for the serum preparation, then centrifuged $(10 \mathrm{~min}, 2000 \mathrm{~g})$. Sera and heparinized plasma were collected, divided into $200 \mu \mathrm{l}$ portions and stored at $-80^{\circ} \mathrm{C}$. Part of the serum, before storage at $-80^{\circ} \mathrm{C}$, was placed in a waterbath at $30^{\circ} \mathrm{C}$ for $15 \mathrm{~h}$. This was arbitrarily defined as "conditioned" serum. Before assaying enzyme activities, the samples were thawed in ice.

Preparation of homogenates from human blood cells

\section{Leukocyte-rich fraction}

Buffy coat cells obtained from citrated human blood $(33 \mathrm{ml})$ were mixed with $8 \mathrm{ml}$ of Volex (Mc Graw Laboratories, Irvine, CA, U.S. A.) in a measuring cylinder. After standing at room temperature for $1 \mathrm{~h}$, the leukocyte-rich layer was collected from the top and the cells were washed twice with phosphate buffered saline.

\section{Erythrocytes}

Erythrocytes were obtained from $5 \mathrm{ml}$ of heparinized blood and were washed three times with phosphate buffered saline.

\section{Thrombocytes}

Thrombocyte concentrates $\left(60 \cdot 10^{12} / 1\right)$ were washed three times with phosphate buffered saline.

Extracts were obtained in two ways from all cells:

Extraction in presence of detergent: A $100 \mathrm{~g} / \mathrm{l}$ solution of Nonidet P40 (LKB, Bromma, Sweden) in water was added to the cells to obtain a concentration of $5 \mathrm{~g} / 1$ Nonidet P40; the cell suspensions were vortexed for $15 \mathrm{~s}$ and centrifuged at $10000 \mathrm{~g}$ for $5 \mathrm{~min}$. The supernatant was divided into $200 \mu \mathrm{l}$ portions and stored at $-80^{\circ} \mathrm{C}$.

Extraction in absence of detergent: The cells were subjected to 2 cycles of freezing and thawing by keeping them at $-80^{\circ} \mathrm{C}$ for $15 \mathrm{~min}$ and at room temperature for $5 \mathrm{~min}$, then sonicated for $10 \mathrm{~s}$. The supernate, obtained after centrifugation at $10000 \mathrm{~g}$ for $5 \mathrm{~min}$, was divided into $200 \mu \mathrm{l}$ portions and stored at $-80^{\circ} \mathrm{C}$.

\section{Enzyme assays}

The enzyme activity with the substrates Hip-Arg and Hip-Lys was determined by a high performance liquid chromatographyassisted assay as described elsewhere (26), with the following modifications: the buffered substrate solutions were both prepared at pH 8.0 (pH measurements were made at room temperature, $18-21^{\circ} \mathrm{C}$ ) and the incubation time was $30 \mathrm{~min}$.

pOH-Hip-Arg and pOH-Hip-Lys-splitting activity was measured by means of a colorimetric assay' (27).

Hydrolysis of the furylacryloyl-substrates (furylacryloyl-AlaArg and furylacryloyl-Ala-Lys) was determined by the method of Plummer \& Kimmel (28), adapted to the following conditions: for furylacryloyl-Ala-Lys: $15 \mu \mathrm{l}$ of sample was mixed with 615 $\mu l$ of buffer (50 mmol/1 HEPES/250 mmol/1 NaCl pH 7.80) previously brought to $37^{\circ} \mathrm{C}$ and preincubated for $2 \mathrm{~min}$ at $37^{\circ} \mathrm{C} ; 70 \mu \mathrm{l}$ of a solution of $6 \mathrm{mmol} / 1$ furylacryloyl-Ala-Lys ( $0.6 \mathrm{mmol} / 1$ final concentration) in distilled water was added. After mixing, the solution was transferred into a cuvette thermostatted at $37^{\circ} \mathrm{C}$, and the decrease in absorbance at $340 \mathrm{~nm}$ was continuously measured for $400 \mathrm{~s}$ (reading against distilled water). For furylacryloyl-Ala-Arg, a similar procedure was followed with $35 \mu \mathrm{l}$ of sample, $595 \mu \mathrm{l}$ of buffer and $70 \mu \mathrm{l}$ of $6 \mathrm{mmol} / \mathrm{l}$ furylacryloyl-Ala-Arg solution. One unit of enzyme activity was defined as the amount of enzyme required to hydrolyse $1 \mu \mathrm{mol}$ of substrate per minute at $37^{\circ} \mathrm{C}$ as determined by the $\Delta \varepsilon$. The esterase activity, determined with the substrate Hip-argininic acid, was measured as follows: to $40 \mu \mathrm{l}$ of substrate solution $(10 \mathrm{mmol} / \mathrm{l} \mathrm{Hip}$-argininic acid/50 mmol/1 HEPES pH 8.0) were added $10 \mu \mathrm{l}$ of the sample; this mixture was incubated for $10 \mathrm{~min}$ at $37^{\circ} \mathrm{C}$ and the reaction stopped with $50 \mu \mathrm{l}$ of $1 \mathrm{~mol} / 1 \mathrm{HCl}$. After addition of $10 \mu \mathrm{l}$ of the internal standard $o$-methylhippuric acid, the hippuric acid was extracted and determined by liquid chromatography as described elsewhere (26). Triplicate determinations were performed for all enzyme assays.

\section{Activators and inhibitors}

The effects of all the enzyme inhibitors and activators were evaluated with the Hip-Arg substrate, using the HPLC-assisted assay (26). Preincubations were performed as follows:

\section{Cobalt chloride}

Samples, diluted 1 plus 4 with physiological saline, were preincubated with $\mathrm{Co}^{++}\left(5 \mathrm{mmol} / 1\right.$ solution of $\mathrm{CoCl}_{2}$ in physiological saline) for $1 \mathrm{~h}$ on ice (final $\mathrm{Co}^{++}$-concentration during assay was $1 \mathrm{mmol} / \mathrm{l})$.

\section{Dithiotreitol}

A $2 \mathrm{mmol} / \mathrm{l}$ solution of dithiotreitol in HEPES, $10 \mathrm{mmol} / \mathrm{l} \mathrm{pH}$ 7.4) was mixed in equal parts with the samples and then preincubated for $1 \mathrm{~h}$ in ice (final dithiotreitol concentration during the assay was $0.2 \mathrm{mmol} / \mathrm{l}$ ).

\section{Diisopropylfluorophosphate}

A solution of $100 \mathrm{~g} / \mathrm{l}$ in isopropanol was diluted with physiological saline to obtain a $10 \mathrm{mmol} / 1$ diisopropylfluorophosphate concentration. Ninety microlitres of each sample were mixed with $10 \mu \mathrm{l}$ of this $10 \mathrm{mmol} / \mathrm{l}$ diisopropylfluorophosphate solution, preincubated in ice for $2 \mathrm{~h}$ and then assayed for enzyme activity (diisopropylfluorophosphate concentration during preincubation was $1 \mathrm{mmol} / 1)$.

Appropriate blanks containing the same amount of isopropanol were assayed to exclude any effect of the isopropanol on enzyme activity. 


\section{Phenylmethylsulphonylfluoride}

A $400 \mathrm{mmol} / \mathrm{l}$ solution of phenylmethylsulphonylfluoride in ethanol was diluted with physiological saline to obtain a $2 \mathrm{mmol} / 1$ phenylmethylsulphonylfluoride solution. Samples were mixed in equal parts with this $2 \mathrm{mmol} / 1$ phenylmethylsulphonylfluoride solution and preincubated for $2 \mathrm{~h}$ in ice before assaying enzyme activity. Appropriate blanks containing the same amount of ethanol were assayed. The phenylmethylsulphonylfluoride solution should be used within 30 min to avoid spontaneous hydrolysis of the inhibitor (29).

\section{1,10-Phenanthroline}

Samples were diluted 1 plus 2 with a solution of $15 \mathrm{mmol} / \mathrm{l}$ 1,10 phenanthroline in physiological saline, then preincubated for $2 \mathrm{~h}$ in ice (phenanthroline concentration during preincubation was $10 \mathrm{mmol} / \mathrm{l}$; the final concentration during assay was $2 \mathrm{mmol} / \mathrm{l})$.

\section{D,L-2-mercaptomethyl-3-guanidinoethylthiopropanoic acid}

$10 \mu \mathrm{l}$ of freshly prepared stock solution of $1200 \mu \mathrm{mol} / 1$ in distilled water (which was first freed of oxygen by passing $\mathrm{N}_{2}$ for $30 \mathrm{~min}$ ) was added to $40 \mu \mathrm{l}$ of the substrate solution (HipArg) before assaying the samples for enzyme activity. (The final concentration of $D, L-2$-mercaptomethyl-3-guanidinoethylthiopropanoic acid was $200 \mu \mathrm{mol} / 1)$. The stock solution of $D, L-2-$ mercaptomethyl-3-guanidinoethylthiopropanoic acid should be used within the hour, to avoid loss of inhibitory capacity.

\section{Ion exchange chromatography}

Two $\mathrm{ml}$ of fresh human serum diluted 1 plus 4 with the equilibration buffer was applied at a flow rate of $21 \mathrm{ml} \cdot \mathrm{cm}^{-2} \cdot \mathrm{h}^{-1}$ to a column $(1.6 \times 35 \mathrm{~cm})$ of DEAE cellulose previously equilibrated in Tris, $0.05 \mathrm{~mol} / \mathrm{l}, \mathrm{pH}$ 7.2. The enzymes were eluted with a linear gradient of $\mathrm{NaCl}$ from 0 to $0.25 \mathrm{~mol} / 1$ in Tris $0.05 \mathrm{~mol} / \mathrm{l}, \mathrm{pH} 7.2$ during $8 \mathrm{~h}$. The effluent was collected in $10 \mathrm{ml}$ fractions. All operations were performed at $4^{\circ} \mathrm{C}$. Protein was determined by its absorbance at $280 \mathrm{~nm}$. Aliquots of the fractions $(100 \mu l)$ were diluted $1+1$ in serum, which had previously been inactivated by keeping it at $56^{\circ} \mathrm{C}$ for $12 \mathrm{~h}$ (this serum contained no arginine carboxypeptidase activity after inactivation). Samples were then assayed for arginine carboxypeptidase activity using the HPLC-assisted assay. The same samples were also assayed for arginine carboxypeptidase activity after placing them at $37^{\circ} \mathrm{C}$ for $2 \mathrm{~h}$.

\section{Results}

Arginine and lysine carboxypeptidase activity in serum and plasma

The results of arginine carboxypeptidase and lysine carboxypeptidase activities of the serum and plasma of the 5 healthy subjects are summarized in table 1 .

Carboxypeptidase activities, when measured with the Hip-Arg substrate, are three times higher (287\%) in the fresh serum samples than in the plasma samples. The lysine carboxypeptidase activity, however, is only $25 \%$ elevated in serum as compared with plasma $(125 \%)$. This is also confirmed by the lysine carboxypeptidase/arginine carboxypeptidase ratio.
Tab. 1. Arginine and lysine carboxypeptidase activity in serum and plasma

\begin{tabular}{lll}
\hline $\begin{array}{l}\text { Arginine } \\
\text { carboxy- } \\
\text { peptidase }\end{array}$ & $\begin{array}{l}\text { Lysine } \\
\text { carboxy- } \\
\text { peptidase }\end{array}$ & $\begin{array}{l}\text { Lysine- } \\
\text { carboxypeptidase/ } \\
\text { arginine } \\
\text { carboxypeptidase } \\
\text { ratio }\end{array}$ \\
\hline
\end{tabular}

\begin{tabular}{lrrr}
\hline Serum & & & \\
1 & 158 & 422 & 2.7 \\
2 & 260 & 483 & 1.9 \\
3 & 149 & 409 & 2.7 \\
4 & 216 & 465 & 2.2 \\
5 & 144 & 356 & 2.5 \\
$\overline{\mathrm{x}} \cdot$ & 185 & 427 & 2.4 \\
$\mathrm{~s}$ & 51 & 50 & 0.3
\end{tabular}

\begin{tabular}{lrrr} 
Plasma & & & \\
1 & 67.7 & 376 & 5.6 \\
2 & 64.8 & 344 & 5.3 \\
3 & 69.0 & 363 & 5.3 \\
4 & 68.6 & 357 & 5.2 \\
5 & 51.9 & 265 & 5.1 \\
$\overline{\mathbf{x}} \cdot$ & 64.4 & 341 & 5.3 \\
s & 7.2 & 44 & 0.2 \\
\hline
\end{tabular}

From five healthy individuals (laboratory staff), blood was taken as described in the Methods section. Carboxypeptidase activities in serum and heparinized plasma were determined with both substrates Hip-Arg (arginine carboxypeptidase) and Hip-Lys (lysine carboxypeptidase) using the HPLC-assisted assay.

\section{Stability}

\section{Stability during assay}

Serum samples were assayed for arginine carboxypeptidase and lysine carboxypeptidase activity (26) using different incubation times at $37^{\circ} \mathrm{C}$. The activities obtained with arginine carboxypeptidase for incubation times of 10, 20 and $30 \mathrm{~min}$ were: 194, 191, and 197 $\mathrm{U} / \mathrm{l}$; with lysine carboxypeptidase: 476,461 , and 455 $\mathrm{U} / \mathrm{l}$.

Even with prolonged incubation, stability was good: arginine carboxypeptidase: 160,158 , and $151 \mathrm{U} / \mathrm{l}$ (other serum, incuibation times 30,60 and $90 \mathrm{~min}$ respectively). This clearly demonstrates that both arginine carboxypeptidase and lysine carboxypeptidase activities measured in fresh serum are stable under assay conditions, i.e. in the presence of the substrate.

\section{Stability as a function of time and temperature}

Fresh serum was kept in a water bath at $30^{\circ} \mathrm{C}$ and assayed for arginine carboxypeptidase and lysine carboxypeptidase activities at different time intervals. The same experiment was performed with fresh heparinized plasma. 
As shown in figure 1, arginine carboxypeptidase and lysine carboxypeptidase activity in serum is unstable: during the first two hours of storage at $30^{\circ} \mathrm{C}$, there is a rapid decrease in their activities, which reach a plateau after about $9 \mathrm{~h}$, then remain stable. The extent of this decrease is much more pronounced for arginine carboxypeptidase then for lysine carboxypeptidase activity. In contrast, in fresh human plasma, the arginine carboxypeptidase and lysine carboxypeptidase activities remain stable over the $21 \mathrm{~h}$ of storage at $30^{\circ} \mathrm{C}$.

It is also remarkable that the plateau of serum arginine carboxypeptidase and lysine carboxypeptidase activities shows values comparable with those of the plasma (serum: arginine carboxypeptidase: $68 \mathrm{U} / 1$, lysine carboxypeptidase: $340 \mathrm{U} / \mathbf{l}$; plasma: arginine carboxypeptidase: $65 \mathrm{U} / 1$, lysine carboxypeptidase: $350 \mathrm{U} / \mathrm{l})$.

The lysine carboxypeptidase/arginine carboxypeptidase ratio, which is initially low (2.1) for the fresh serum, gradually increases with time until it reaches a stable value of 5.1 , which is comparable to the plasma ratio (5.4).

The same experiment was repeated keeping the samples at room temperature and at $37^{\circ} \mathrm{C}$. At room temperature, the decrease in arginine carboxypeptidase and lysine carboxypeptidase activities progresses much more slowly and reaches a plateau after about four days of storage, while at $37^{\circ} \mathrm{C}$ both activities stabilize after $2 \mathrm{~h}$. These stable plasma arginine carboxypeptidase and lysine carboxypeptidase activities and unstable serum enzyme activities, which stabilize at about the same value as the plasma enzyme activities, were seen in all the samples studied.
In order to facilitate the precise description of further experiments, we define arbitrarily the unstable fraction of the arginine carboxypeptidase and lysine carboxypeptidase activities in serum as carboxypeptidase $U$ activities, whereas the stable arginine carboxypeptidase and lysine carboxypeptidase activities in plasma and "conditioned" sera are carboxypeptidase $\mathrm{N}$ activities.

\section{Influence of heparin}

To $90 \mu$ of the fresh serum samples and the "conditioned" serum samples were added either $10 \mu$ l of distilled water (a), or $10 \mu \mathrm{l}$ of heparin in distilled water: $2 \mathrm{~g} / 1$ (b) or $10 \mathrm{~g} / 1$ (c). The normal heparin concentration in heparinized plasma is about $0.2 \mathrm{~g} / 1$ (30). All samples were preincubated in ice for $2 \mathrm{~h}$, then assayed for arginine carboxypeptidase and lysine carboxypeptidase activities (HPLC-assay, pH 8.0, 30 min incubation time).

Heparin in concentrations of 0.2 and $1.0 \mathrm{~g} / 1$ inhibits the arginine carboxypeptidase $\mathrm{N}$ activity by $5 \%$, and the arginine carboxypeptidase $U$ activity by $25 \%$. Lysine carboxypeptidase activities, both carboxypeptidase $\mathrm{N}$ and carboxypeptidase $\mathrm{U}$, were not influenced by heparin. These results show that heparin cannot be held responsible for the absence of carboxypeptidase $U$ activity in heparinized plasma. The small degree of inhibition of the arginine carboxypeptidase $U$ activity by heparin explains why plasma arginine carboxypeptidase activities are about $5 \%$ to $10 \%$ lower than arginine carboxypeptidase activities in "conditioned" serum.

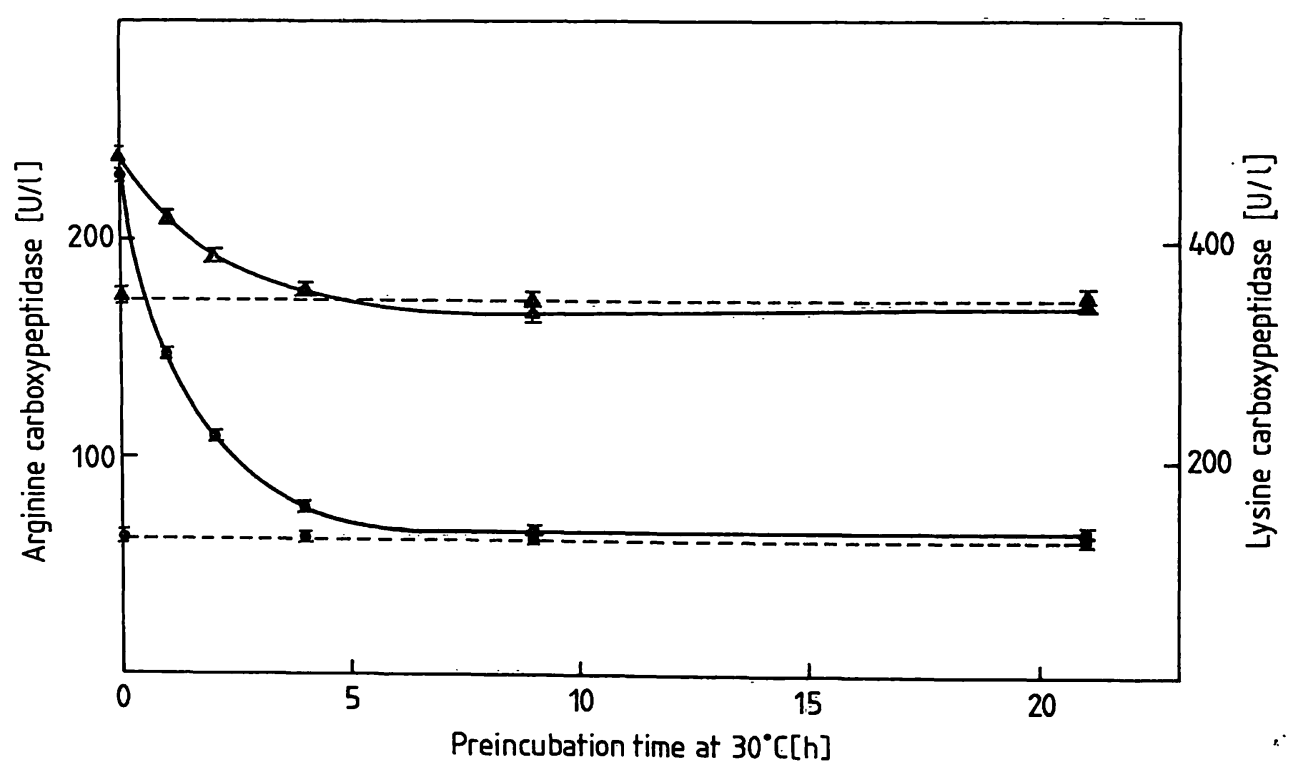

Fig. 1. Stability of arginine and lysine carboxypeptidase activity in human serum and plasma.

Human serum $(-)$ and plasma $(--)$ were kept in a water bath at $30^{\circ} \mathrm{C}$ and assayed for arginine (e) and lysine $(\Delta)$ carboxypeptidase activity at different time intervals. The range for the triplicate determinations is indicated. 


\section{Possibility of an activator}

To evaluate whether the carboxypeptidase $U$ activity in fresh human serum could be due to the presence of an activator - which should be unstable - additional experiments were performed. Results show that the fresh serum does not contain an activator or an inhibitor for these carboxypeptidase activities (tab. 2).

Tab. 2. Experiments to evaluate the presence of a carboxypeptidase $\mathrm{N}$ activator or inhibitor in human serum

\begin{tabular}{lll}
\hline Sample & $\begin{array}{l}\text { Arginine } \\
\text { carboxy- } \\
\text { peptidase } \\
(U / 1)\end{array}$ & $\begin{array}{l}\text { Lysine } \\
\text { carboxy- } \\
\text { peptidase } \\
(U / 1)\end{array}$ \\
\hline Fresh serum (A) & 202 & 467 \\
"Conditioned" serum (B) & 69 & 354 \\
A + B (1+1) & $131(136)$ & $407(411)$ \\
A + B (1+5) & $89(91)$ & $361(373)$ \\
\hline
\end{tabular}

Fresh serum and "conditioned" serum were mixed 1 plus 1 and 1 plus 5 , then assayed for arginine carboxypeptidase and lysine carboxypeptidase activities. The values between parentheses indicate the theoretical enzyme activities if no activation or inhibition between $A$ and $B$ occurs.

\section{Enzyme activity in human blood cells}

In order to exclude the possibility that the carboxypeptidase $U$ activity generated during serum formation is derived from human blood cells, we determined enzyme activity in human leukocytes, erythrocytes and thrombocytes using Hip-Arg and Hip-Lys as substrates.

Leukocytes and erythrocytes did not contain any measurable enzyme activity on these substrates, and thrombocytes showed a very low carboxypeptidase activity, only detectable with prolonged incubation. These findings are in accordance with earlier studies where human polymorphonuclear leukocytes did not hydrolyze Hip-Lys (31), haemolyzed red blood cells showed no activity with Hip-Arg (32), and thrombocytes split Hip-Lys very slowly (32).

\section{Influence of recalcification of citrate plasma}

For direct proof that the carboxypeptidase $U$ activity is generated during the coagulation process, we recalcified a citrate plasma ( $0.129 \mathrm{~mol} / \mathrm{l} \mathrm{Na}$-citrate $)$ with an equal volume of $\mathrm{CaCl}_{2} 20 \mathrm{mmol} / \mathrm{l}$ (in HEPES 20 $\mathrm{mmol} / \mathrm{l}, \mathrm{pH}$ 7.4) and placed it in ice for $1 \mathrm{~h}$. After centrifugation we determined an arginine carboxypeptidase activity of $149 \mathrm{U} / \mathrm{l}$ in the supernate serum, while the original citrated plasma had an activity of $59.6 \mathrm{U} / 1 . \mathrm{Ca}^{++} 20 \mathrm{mmol} / 1 \mathrm{did}$ not effect arginine carboxypeptidase activity.
Characterization of the carboxypeptidase $U$ activity

\section{pH Optimum}

Fresh serum and "conditioned" serum were assayed for arginine carboxypeptidase activity in HEPES 50 $\mathrm{mmol} / 1$ at $\mathrm{pH}$-values ranging from 6.5 to 8.5 (fig. 2). The difference between the two $\mathrm{pH}$-curves obtained shows the $\mathrm{pH}$-profile of the arginine carboxypeptidase $\mathrm{U}$ activity. Arginine carboxypeptidase $\mathrm{N}$ showed a $\mathrm{pH}$ optimum in the range of 8.0 to 8.2 , which is the same as that termined before with the same assay (26).

At $\mathrm{pH} 8.0$ to 8.2 however, the arginine carboxypeptidase $U$ activity is about $15 \%$ below its optimum, which is around $\mathrm{pH} 7.5$ to 7.8. Thus, arginine carboxypeptidase $\mathrm{N}$ has a different $\mathrm{pH}$ optimum from that of arginine carboxypeptidase $U$ activity.

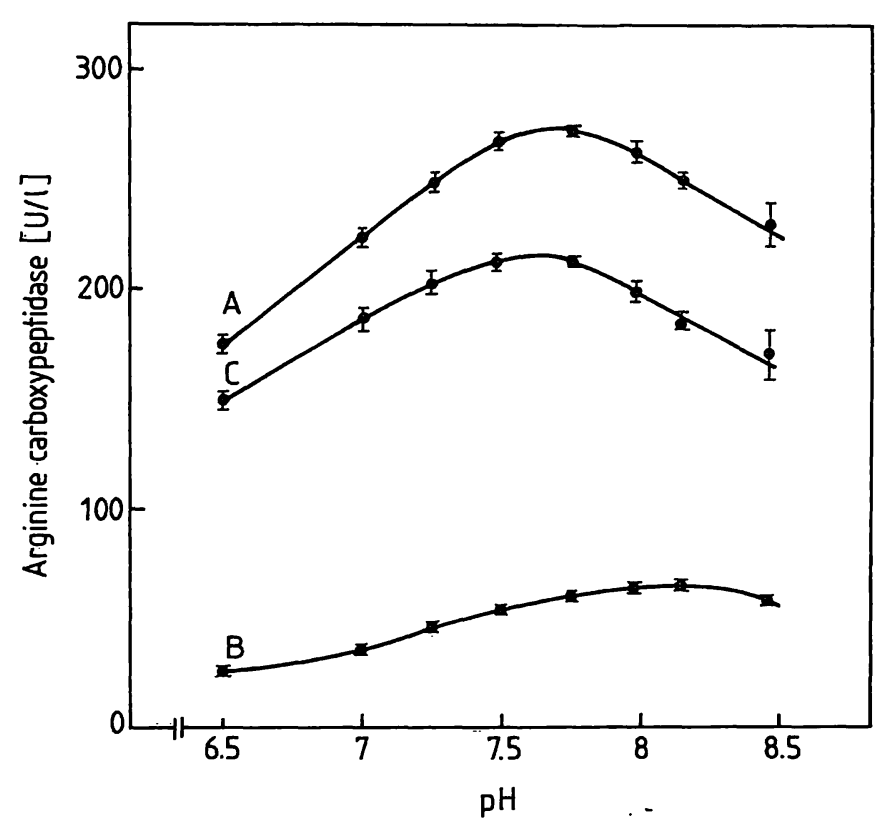

Fig. 2. Effect of $\mathrm{pH}$ on the arginine carboxypeptidase activity of fresh serum and "conditioned" serum. Fresh serum (A) and "conditioned" serum (B) were assayed for arginine carboxypeptidase activity in $50 \mathrm{mmol} / 1$ HEPES buffer at different $\mathrm{pH}$. The difference between the two pH-curves obtained shows the pH-profile of the arginine carboxypeptidase $U$ activity (C). The range for the triplicate determinations is indicated.

\section{Activation and inhibition}

The effect of several enzyme inhibitors and activators on arginine carboxypeptidase $\mathrm{N}$ and $\mathrm{U}$ activities was determined using Hip-Arg as the substrate (tab. 3). $\mathrm{Co}^{2+}(1 \mathrm{mmol} / \mathrm{l})$, a well known activator of carboxypeptidase $N$ (32), increased the arginine carboxypeptidase $\mathrm{N}$ activity, but inhibited the arginine carb- 
Tab. 3. Activation and inhibition of arginine carboxypeptidase

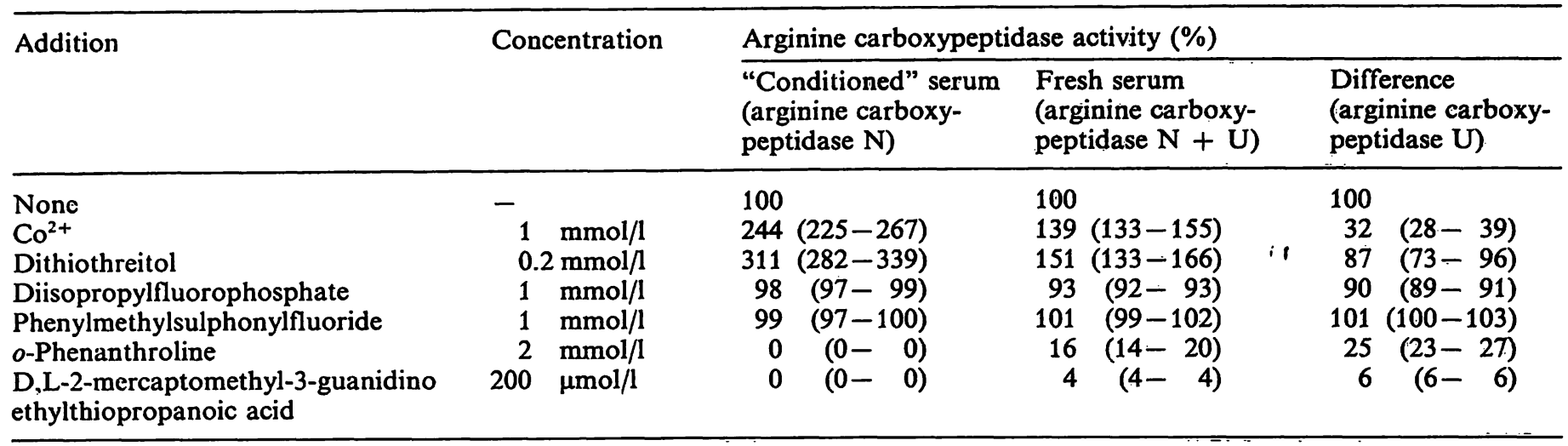

Samples were incubated with the inhibitors or activators as described in the Materials and Methods section, then assayed for arginine carboxypeptidase activity using the HPLC-assisted assay. The data represent the mean for three separate experiments. The values in brackets indicate the range.

oxypeptidase U activity. Diisopropylfluorophosphate $(1 \mathrm{mmol} / \mathrm{l})$ and phenylmethylsulphonylfluoride $(1 \mathrm{mmol} / \mathrm{l})$ had no influence on either enzyme activity, which indicates that carboxypeptidase $U$ is not a serine protease. Dithiotreitol $(0.2 \mathrm{mmol} / \mathrm{l})$ strongly enhanced the activity of arginine carboxypeptidase $\mathrm{N}$, but did not increase arginine carboxypeptidase $U$ activity. $o$-Phenanthroline $(2 \mathrm{mmol} / \mathrm{l})$ completely inhibited arginine carboxypeptidase $\mathrm{N}$, but carboxypeptidase $U$ showed a residual activity of $25 \%$. The carboxypeptidase $\mathrm{N}$ inhibitor $D, L-2$-mercaptomethyl3-guanidinoethylthiopropanoic acid (36) inhibited arginine carboxypeptidase $\mathrm{N}$ and $\mathrm{U}$ to the same extent.

\section{Substrate specificity}

Table 4 summarizes the results of the substrate specificity of both carboxypeptidases, $\mathrm{N}$ and $\mathrm{U}$.
As already shown in the first experiments, carboxypeptidase $U$ activity is much more pronounced for Hip-Arg than for Hip-Lys. We see similar results for the $p$-hydroxy-hippuryl substrates. In contrast, the carboxypeptidase $U$ activity was low with furylacryloyl-Ala-Arg, and no carboxypeptidase $U$ activity could be demonstrated with furylacryloyl-Ala-Lys. This is in sharp contrast with carboxypeptidase $\mathrm{N}$ itself, which is very active towards these substrates.

The esterase activity of carboxypeptidase $\mathrm{N}$ measured with Hip-argininic acid, first described by Erdös et al. (32), is high in comparison with its peptidase activity. Nearly no carboxypeptidase $U$ esterase activity could be demonstrated with the Hip-argininic acid substrate. Activities measured in "conditioned" sera and in plasma are very similar, confirming that the carboxypeptidase $\mathrm{N}$ activity is, indeed, measured in these samples. For the Hip-Arg and $p \mathrm{OH}-\mathrm{Hip}-\mathrm{Arg}$ sub-

Tab. 4. Substrate specificity of carboxypeptidases in human serum and plasma

\begin{tabular}{|c|c|c|c|c|c|c|}
\hline & \multicolumn{3}{|l|}{ Sample 1} & \multicolumn{3}{|l|}{ Sample 2} \\
\hline & Fresh serum & $\begin{array}{l}\text { "Condi- } \\
\text { tioned" } \\
\text { serum }\end{array}$ & $\overline{\text { Plasma }}$ & Fresh serum & $\begin{array}{l}\text { "Condi- } \\
\text { tioned" } \\
\text { serum }\end{array}$ & Plasma \\
\hline $\begin{array}{l}\text { Hip-Arg }(U / 1) \\
\text { Hip-Lys }(U / 1) \\
\text { Lys/Arg ratio }\end{array}$ & $\begin{array}{r}261 \\
484 \\
1.9\end{array}$ & $\begin{array}{c}67.0 \\
343 \\
5.1\end{array}$ & $\begin{array}{c}62.0 \\
340 \\
5.5\end{array}$ & $\begin{array}{r}164 \\
446 \\
2.7\end{array}$ & $\begin{array}{c}72.0 \\
365 \\
5.1\end{array}$ & $\begin{array}{c}68.1 \\
373 \\
5.5\end{array}$ \\
\hline $\begin{array}{l}\text { p-OH-Hip-Arg }(\mathrm{U} / \mathrm{l}) \\
\text { p-OH-Hip-Lys (U/l) } \\
\text { Lys/Arg ratio }\end{array}$ & $\begin{array}{c}78.0 \\
123 \\
1.6\end{array}$ & $\begin{array}{r}20.1 \\
83.8 \\
4.2\end{array}$ & $\begin{array}{r}17.2 \\
82.2 \\
4.8\end{array}$ & $\begin{array}{c}52.7 \\
112 \\
2.1\end{array}$ & $\begin{array}{r}19.6 \\
88.4 \\
4.5\end{array}$ & $\begin{array}{r}17.4 \\
91.2 \\
5.2\end{array}$ \\
\hline $\begin{array}{l}\text { Furylacryloyl-Ala-Arg (U/1) } \\
\text { Furylacryloyl-Ala-Lys (U/1) } \\
\text { Lys/Arg ratio }\end{array}$ & $\begin{array}{r}192 \\
605 \\
3.2\end{array}$ & $\begin{array}{r}164 \\
612 \\
3.7\end{array}$ & $\begin{array}{r}169 \\
612 \\
3.6\end{array}$ & $\begin{array}{r}172 \\
631 \\
3.7\end{array}$ & $\begin{array}{r}152 \\
615 \\
4.0\end{array}$ & $\begin{array}{r}152 \\
620 \\
4.1\end{array}$ \\
\hline Hip-argininic acid (U/l) & 1103 & 1024 & 1054 & 1138 & 1116 & 1120 \\
\hline
\end{tabular}

Carboxypeptidase activities with different synthetic substrates currently used for carboxypeptidase $\mathrm{N}$ activity determinations $(26-28,32-25)$ were determined in fresh sera, "conditioned" sera and heparinized plasma from two donors. 
strates, activities in "conditioned" serum are about $10 \%$ higher than activities in plasma, while for the Hip-Lys and $p \mathrm{OH}-\mathrm{Hip}$-Lys substrates, the activities are about equal. This can be explained by the effect of heparin, which was found to have a small inhibitory effect on arginine carboxypeptidase activities.

Influence of $D, L-2$-mercaptomethyl-3-guanidinoethylthiopropanoic acid on routine coagulation tests

Since the carboxypeptidase $U$ activity appears during coagulation and consequently only is present in serum, it would be of interest to know if an inhibitor of this enzyme could disturb the coagulation cascade. Three citrated plasma samples were mixed with a solution of $D, L-2$-mercaptomethyl-3-guanidinoethylthiopropanoic acid in oxygen-free distilled water to obtain a final $D, L$-2-mercaptomethyl-3-guanidino ethylthiopropanoic acid concentration of $185 \mu \mathrm{mol} / 1$, which completely inhibited carboxypeptidase $\mathrm{N}$ and $\mathrm{U}$ activities. In these plasma samples with and without $D, L$-2-mercaptomethyl-3-guanidinoethylthiopropanoic acid, we determined the following routine coagulation parameters: the prothrombin time by the Quick one-stage method, the partial thromboplastin time with kaolin, and the Thrombotest ${ }^{\mathrm{TM}}$ (37). All three tests showed normal values for all samples assayed, and no significant difference was found between the samples with or without $D, L-2$-mercaptomethyl-3-guanidinoethylthiopropanoic acid.

\section{Ion exchange chromatography}

In order to find out if another carboxypeptidase besides carboxypeptidase $\mathrm{N}$ is present in human serum, we performed DEAE-cellulose ion-exchange chromatography on fresh human serum. To detect the unstable carboxypeptidase activity (carboxypeptidase $U$ ), it is necessary to use fresh serum, and to work at $4{ }^{\circ} \mathrm{C}$, measuring enzyme activity in the fractions after mixing with serum devoid of carboxypeptidase activity. Inactivation of the fractions by placing them at $37^{\circ} \mathrm{C}$ for $2 \mathrm{~h}$ reveals the stable carboxypeptidase activity (carboxypeptidase N). From the results shown in figure 3 , we can conclude that ion-exchange chromatography demonstrates the presence of two carboxypeptidases in human serum, one of them being thermolabile (carboxypeptidase $U$ ). The overall yield of enzymatic activity was $75 \%$. Measurement of $\mathrm{Co}^{2+}$ activation and esterase activity on fractions of Peak I (carboxypeptidase U) and Peak II (carboxypeptidase N) confirmed our previous results: carboxypeptidase $\mathrm{N}$ was activated by $\mathrm{Co}^{2+}(1 \mathrm{mmol} / \mathrm{l})$ and showed a high esterase activity, while carboxypeptidase $U$ showed $50 \%$ inhibition with $\mathrm{Co}^{2+}$ and yielded no esterase activity.

\section{Discussion}

The presence of a carboxypeptidase B-type enzyme in human plasma that inactivates bradykinin was first described by Erdös \& Sloane in 1962 (33) and named carboxypeptidase N. Since changes in the blood level of this enzyme may be significant in various disease states, carboxypeptidase $\mathrm{N}$ activities in serum or plasma were previously determined in a variety of pathological conditions.

During our studies on arginine carboxypeptidase determinations in sera, we observed a marked instability of these activities. This instability has not been pre-

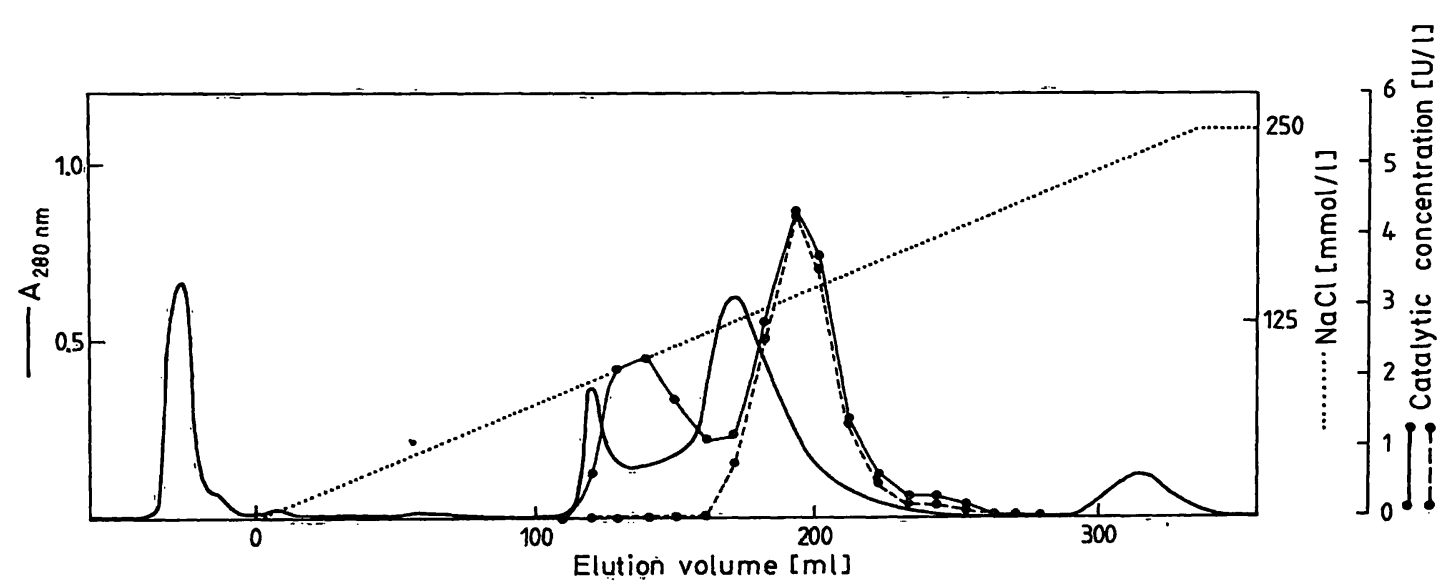

Fig. 3. DEAE-cellulose chromatography of human serum. $2 \mathrm{ml}$ of fresh human serum diluted 1 plus 4 with the equilibration buffer was applied at a flow rate of $21 \mathrm{ml} \cdot \mathrm{cm}^{-2} \cdot \mathrm{h}^{-1}$ to a column $(1.6 \times 35 \mathrm{~cm})$ of DEAE-cellulose previously equilibrated in $0.05 \mathrm{~mol} / 1$ Tris, $\mathrm{pH} 7.2$. The enzymes were eluted with a linear gradient of $\mathrm{NaCl}$ from 0 to $0.25 \mathrm{~mol} / 1 \mathrm{in} 0.05 \mathrm{~mol} / 1$ Tris, pH 7.2 during $8 \mathrm{~h}$. The effluent was collected in $10 \mathrm{ml}$ fractions. $100 \mu \mathrm{l}$ aliquots of the fractions were diluted $1+1$ in serum which was previously inactivated by keeping it at $56^{\circ} \mathrm{C}$. Samples were then assayed for arginine carboxypeptidase activity (-) . The same samples were also assayed for arginine carboxypeptidase activity after keeping them at $37^{\circ} \mathrm{C}$ for $2 \mathrm{~h}(0-0)$. 
viously reported in the literature. In further experiments, it became clear that fresh sera contain a high enzymatic activity as regards carboxy-terminal arginine removal, while this activity is much lower in heparinized plasma or in sera kept at room temperature for several hours. In this report, we describe for the first time the presence of an unstable arginine carboxypeptidase activity in fresh human serum, which we call carboxypeptidase $U$ activity.

The carboxypeptidase $U$ activity has some characteristics in common with the human plasma carboxypeptidase N: both enzymes cleave Hip-Arg and HipLys, are not inhibited by the serine proteinase inhibitors diisopropylfluorophosphate and phenylmethylsulphonylfluoride, and, most importantly, both are inhibited by the carboxypeptidase $\mathrm{N}$ inhibitor $D, L-2-$ mercaptomethyl-3-guanidinoethylthiopropanoic acid. Arginine carboxypeptidase $U$ is inhibited by $o$-phenanthroline, but not to the same extent as the arginine carboxypeptidase $\mathrm{N}$ activity.

However, some characteristics clearly differentiate carboxypeptidase $U$ activities from carboxypeptidase $\mathrm{N}$ activities: the carboxypeptidase $\mathrm{U}$ activity towards Hip-Arg is higher than towards Hip-Lys, while carboxypeptidase $\mathrm{N}$ cleaves Hip-Lys about five times faster than Hip-Arg. Furylacryloyl-Ala-Arg was cleaved only very slowly and furylacryloyl-Ala-Lys not at all by carboxypeptidase U. Moreover, carboxypeptidase U showed no esterase activity when measured with the substrate Hip-argininic acid. The $\mathrm{pH}$ optimum of the arginine carboxypeptidase $U$ activity (pH 7.7) was also different from that of carboxypeptidase $\mathrm{N}(\mathrm{pH} 8.1)$.

We directly demonstrated that, during the process of clot formation, a new enzyme activity appears, clearly different from normal carboxypeptidase $\mathrm{N}$ in terms of stability, substrate specificity, effect of activators and inhibitors, and $\mathrm{pH}$-optimum. Ion exchange chromatography on DEAE-cellulose is used as the first step in the purification of carboxypeptidase $U$, because it provides a good separation of carboxypeptidase $\mathrm{N}$ and carboxypeptidase $\mathrm{U}$, and the yield is high. Purification of carboxypeptidase $U$ to homogeneity will be difficult, owing to its marked instability.

A hypothesis for the appearance of this unstable enzyme activity during coagulation lies within the structure of the carboxypeptidase $\mathrm{N}$ itself. Carboxypeptidase $\mathrm{N}$ is a 280000 relative molecular mass tetrameric enzyme consisting of two $M_{\mathrm{r}} 48000$ and two $M_{\mathrm{r}} 83000$ subunits $(38,39)$.

The $M_{\mathrm{r}} 48000$ subunit possesses the full enzymatic activity of the intact enzyme with ester and small peptide substrates, but loses $75 \%$ of its activity when stored for $2 \mathrm{~h}$ at $37^{\circ} \mathrm{C}$ (39). Proteolysis of the intact enzyme or of the $M_{\mathrm{r}} 48000$ subunit with plasmin, trypsin or urinary kallikrein yielded fragments with increased esterase and peptidase activity, but with decreased stability (39). During the coagulation process, many proteolytic enzymes are activated, and this could cause a partial proteolysis' of carboxypeptidase $\mathrm{N}$, resulting in increased activity and a lesser stability. However, the carboxypeptidase $U$ in our experiments had no esterase activity. Moreover, if a part of the carboxypeptidase $\mathrm{N}$ is converted into unstable subunits, the carboxypeptidase $\mathrm{N}$ activity measured in "conditioned" serum should be considerably lower than in plasma. It therefore seems unlikely that the carboxypeptidase $U$ activity originates from a subunit formation of carboxypeptidase $\mathrm{N}$.

Another hypothesis is that one of the enzymes that takes part in the coagulation cascade, and is activated during clot formation, exhibits a carboxypeptidase $U$ activity. Many of these coagulation enzymes, being serine proteinases, are inhibited by diinopropylfluorophosphate or phenylmethylsulphonylfluoride. This was not the case for the carboxypeptidase $U$ activity. Addition of $\bar{D}, L$-2-mercaptomethyl-3-guanidino ethylthiopropanoic acid to citrate plasma did not cause a significant increase in coagulation time (prothrombin time, partial thromboplastin time with kaolin, thrombotest). This excludes a major role for this enzyme in the coagulation system.

Release of the carboxypeptidase $U$ activity from human blood cells seems unlikely, since we could not detect any carboxypeptidase $\mathrm{N}$ or carboxypeptidase $U$ activity in leukocytes or erythrocytes and only very little activity in thrombocytes.

The carboxypeptidase $U$ is also clearly different from the recently identified urinary carboxypeptidase, which is stable at $37^{\circ} \mathrm{C}$ and exhibits an esterase activity (40).

Sheikh \& Kaplan (41) reported that arginine removal from bradykinin in serum occurs at a rate exceeding that of heparinized plasma and is more rapid than can be attributed to carboxypeptidase $\mathrm{N}$. This important observation is consistent with the presence of the carboxypeptidase $U$ activity we have demonstrated, which preferentially removes C-terminal arginine.

Carboxypeptidase $\mathrm{N}$ is recognized to be an important enzyme, mainly because of its anaphylatoxin-inhibiting characteristics. Many papers deal with the determination of carboxypeptidase $\mathrm{N}$ activities, using different substrates, in human serum of patients with 
various pathologies. Those working in this field should pay great attention in collecting samples. In order to determine only the carboxypeptidase $\mathrm{N}$ activity, we can recommend

(1) keeping serum samples at $37^{\circ} \mathrm{C}$ for $2 \mathrm{~h}$ before assay;

\section{References}

1. Erdös, E. G. (1979) In: Bradykinin, Kallidin and Kallikrein, Handbook of Experimental Pharmacology, Vol. 25 (Suppl.), pp. 427-487.

2. Bokish, V. A. \& Müller-Eberhard, H. J. (1970) J. Clin. Invest. 49, 2427-2436.

3. Gorski, J., Hugli, T. \& Müller-Eberhard, H. J. (1979) Proc. Natl. Acad. Sci. USA 76, 5299-5302.

4. Belew, M., Gerdin, B., Lindeberg, G., Porath, J. \& Wallin, R. (1980) Biochim. Biophys. Acta 621, 169-178.

5. Perryman, M., Knell, D. \& Roberts, R. (1984) Clin. Chem. $30,662-664$.

6. Hendriks, D., Soons, J., Scharpé, S., Wevers, R., van Sande, M. \& Holmquist, B. (1988) Clin. Chim. Acta 172, 253260.

7. Skidgel, R. A., Johnson, A. R. \& Erdös, E. G. (1984) Biochem. Pharmacol. 33, 3471-3478.

8. Hendriks, D., Verkerk, R., Vanhoof, G., De Meester, I., van Sande, M. \& Scharpé, S. (1987) Biochem. Soc. Trans. $16,359-360$.

9. Corbin, N. C., Hugli, T. E. \& Müller-Eberhard, H. J. (1975) Anal. Biochem. 73, 41-51.

10. Erdös, E. G., Wohler, I. M., Levine, M. I. \& Westerman, M. P. (1965) Clin. Chim. Acta 11, 39-43.

11. Gerhardt, W., Kallos, P. \& Lundquist, A. (1982) Int. Archs. Allergy Appl. Immun. 69, 206-209.

12. Koheil, A., Corey, M. \& Forstner, G. (1979) Clin. Invest. Med. 2, 99-103.

13. Lieberman, J. (1975) Am. Rev. Resp. Dis. 111, 100-102.

14. Mathews, K. P., Pan, P. M., Gardner, N. J. \& Hugli, T. E. (1980) Ann. Int. Med. 93, 443-445.

15. Rohatgi, P. K. \& Ryan, J. W. (1982) Am. Rev. Resp. Dis. 125,115 .

16. Schweisfurth, H., Heinrich, J., Brugger, E., Wernze, H., Wichmann, J. \& Ertl, G. (1983) Praxis Klin. Pneumol. 37, $562-564$.

17. Delk, A., Durie, P., Fletcher, T. \& Largman, C. (1985) Clin. Chem. 31, 1294-1300.

18. Schweisfurth, H. \& Burghardt, W. (1983) Z. Gastroenterol. $24,397$.

19. Schweisfurth, H., Heinrich, J., Brugger, E. \& Burghardt, W. (1984) Dtsch. Med. Wochenschr. 109, 166-169.

20. Schweisfurth, H., Schmidt, M., Brugger, E., Maiwald, L. \& Thiel, H. (1985) Clin. Biochem. 18, 242-246.
(2) using heparinized plasma samples; or

(3) measuring esterase activity in either sera or plasma.

Current data on carboxypeptidase $\mathrm{N}$ activities in sera should be carefully evaluated.

21. Schweisfurth, H. \& Thiel, H. (1987) Atemw. Lungenkrkh. $13,138-140$.

22. Schweisfurth, H., Pickert, E., Gramer, E. \& Reiners, C. (1987) Clin. Biochem. 20, 43-46.

23. Sommer, H., Schweisfurth, H. \& Schultz, M. (1986) Enzyme $35,181-188$.

24. Streeten, D. H., Kerr, L. P., Kerr, C. B., Prior, J. C. \& Dalakos, T. G. (1972) Lancet $I I, 1048-1053$

25. Vogel, A. J. (1970) In: Practical Organic Chemistry, p. 584, Longman, London.

26. Hendriks, D., Scharpé, S. \& van Sande, M. (1985) Clin. Chem. 31, 1936-1939.

27. Hendriks, D., Scharpé, S., van Sande, M., Lommaert, M. P. \& Kasahara, Y. (1987) Anal. Biochem. 164, 90-95.

28. Plummer, T. H. \& Kimmel, M. T. (1980) Anal. Biochem. $108,348-353$.

29. Barrett, A. J. \& Salvesen, G. (1986) In: Proteinase Inhibitors, Research Monographs in Cell and Tissue Physiology, Vol. 12, p. 88.

30. Tietz, N. W. (1986) In: Textbook of Clinical Chemistry, p. 485 , W. B. Saunders Company, PA.

31. Nakahara, M. (1980) Biochem. Pharmacol. 29, 2235-2239.

32. Erdös, E. G., Yang, H. J., Tague, L. L. \& Manning, N. (1967) Biochem. Pharmacol. 16, 1287-1297.

33. Erdös, E. G. \& Sloane, E. M. (1962) Biochem. Pharmacol. $11,585-592$.

34. Hendriks, D., van Sande, M. \& Scharpé, S. (1986) Clin. Chim. Acta 157, 103-108.

35. Marceau, F., Drumheller, A., Gendreau, M., Lussier, A. \& St.-Pierre, S. (1987) J. Chromatog. 266, 173-177.

36. Plummer, T. H. \& Ryan, T. J. (1981) Biochem. Biophys. Res. Commun. 98, 448-454.

37. Dacie, J. V. \& Lewis, S. M. (1975) In: Practical Haematology, Churchill Livingstone, New York, NY.

38. Plummer, T. H. \& Hurwitz, M. J. (1978) J. Biol. Chem. 253, 3907-3912.

39. Levin, J., Skidgel, R. A. \& Erdös, E. G. (1982) Proc. Natl. Acad. Sci. USA 79, 4618-4622.

40. Skidgel, R. A., Davis, R. M. \& Erdös, E. G. (1984) Anal. Biochem. 140, 520-531.

41. Sheikh, J. A. \& Kaplan, A. P. (1986) Biochem. Pharmacol. 35, 1957-1963.

Prof. Dr. S. Scharpé

Department of Medical Biochemistry

University of Antwerp

B-2610 Wilrijk 
